\title{
市民・NPO・企業相互の環境教育 コラボレーションをすすめるために
}

川嶋 直

\section{はじめに}

市民・NPO ・企業と環境教育の全体を俯瞰 することは難しい。市民・NPOの活動も様々な 場面で広がりを見せ、企業に打ける環境教育も 近年急激に進みつつある。この稿では、主に自 然体験を中心とした環境教育の二つのトピック を挙げ、その活動の中心としての自然学校を紹 介し、もう一方の環境教育の形としての生活系 環境教育に触れ、最近の企業の環境教育などの 様子を探りながら、こうした活動を進めてゆく ために欠かせないコラボレーションについて述 ベる。

\section{清里環境教育フォーラム (1987年) から、「愛・地球博」(2005年)へ}

わが国における「環境教育」は、環境庁・文 部省 (いずれも当時)などが担当官を置いて取り 組みを始める (1980年代後半) 以前から自然保 護団体などを中心に市民やNPOの手によって始 められていた。当時、それぞれの活動は必ずし も「環境教育」と呼ばれていた訳ではないが、 1987年に山梨県の清里で開催された「第 1 回清 里フォーラム (翌年からは「清里環境教育フォー ラム」と改称)」(同実行委員会主催)の頃から は、徐々に自らの活動を環境教育と位置づける ようになっていった。

この清里の年 1 回のフォーラムは「5年後に

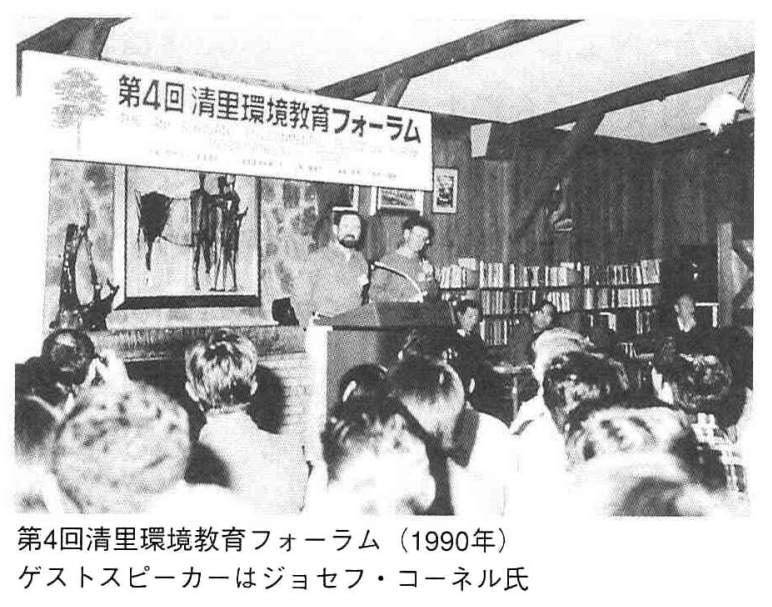

本を出版して解散する」という当初の目標どお り1991年秋の集まりで一区切りをつけ、翌年秋 に「日本型環境教育の提案 (小学館、1992年、 改訂版2000年)」を発刊することが出来たが、引 き続きこの集まりは任意団体「日本環境教育つ オーラム」として会員制の団体を発足させ、 1997年には環境庁所轄の社団法人となった。

2005年、「愛・地球博」に打いて「森の自然学 校・里の自然学校」という (財) 日本国際博覧会 協会の主催事業を、上記フォーラムが協会から 企画運営の受託をした。185日の期間中に両自 然学校は 54 万人の入場者を迎え、森の中での体 験と参加を通して「自然学校」「インタープリタ 一」などの言葉を広めることが出来た。二つの 自然学校には期間中 100 人を超えるインタープ リターがほぼ常勤で働いた。100人のうち3割は 全国から集められた若手のプロのインタープリ ターたち、そして残る7割は東海地区で公募さ れ、半年間の研修を経てインタープリターとし 
て選考・採用された市民たちだった。環境教育 を伝える手段としてのインタープリテーション （自然解説活動）に関心を寄せる市民は確実に増 えてきている。この自然学校は巨大イベントの 一部であり、短時間\&大人数\&全世代対応とい う、これまでにない環境・規模でのプログラム 実施だったが、「ここは万博の良心だ」「自然の 㩚智 (「愛・地球博」のテーマ)をまさに体現し ている」などの来場者からの高い評価もいただ き、参加者の様子からも「こうした活動が市民 からも求められている」ことを実感することが 出来た。

「愛・地球博」は、上記の「森・里の自然学校」 のほかにも「地球市民村」をはじめとして様々 な形での市民参加によって支えられた。35年前 の大阪万博でも、20年前の筑波科学万博でも、 市民は博覧会の外から博覧会への異議申し立て

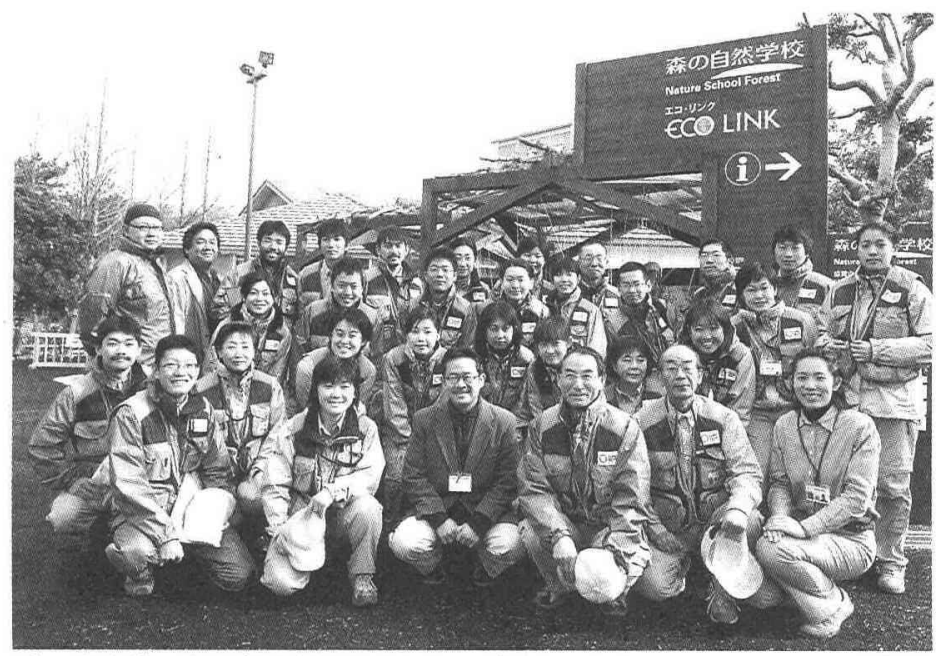

愛・地球博 森の自然学校のインタープリターたち (2005年3月25日万博初日の朝)

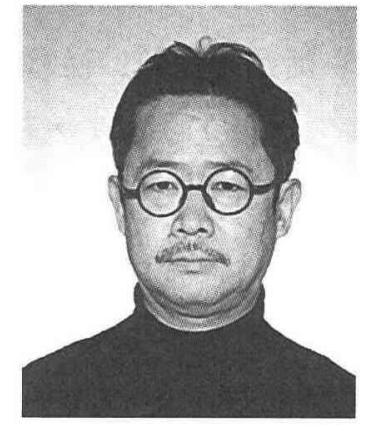

\section{PROFILE}

川嶋 直

(かわしま ただし 1953年生) 立教大学大学院異文化コミュニ ケーション研究科特任教授、財 団法人キープ協会常務理事 専門：自然体験型環境教育、野 外教育、ワークショップ、イン タープリテーション

をすることしか出来なかったが、今回は計画段 階では博覧会の会場を変更させることに成功 し、期間中には運営の重要なパートを担うな ぞ、市民の果たした役割は非常に大きかった。

\section{環境教育の場としての自然学校}

自然体験型環境教育の拠点施設として「自然 学校」と呼ばれる施設がある。現在わが国には 数千の自然学校が存在しているという調査もあ るが、これは公立の少年自然の家など も含めた「自然の中での、体験を通し た、公的学校以外の学びの場」という くくりの総数である。1980年代中ごろ から現れた、独立自営型つまり民設民 営型の自然学校は全国で数百程度とい われている。すべての自然学校が「環 境教育」を明言している訳ではないが、 前記フォーラムの加盟団体に日本を代 表する大きな自然学校の多くが入って いることから見ても、「環境教育を実 
践する場としての自然学校」という位置付けは 出来るであろう。

現在各地で運営されている自然学校には、活 動場所、対象者、活動の種類、経営主体など 様々なケースがある。設立の経緯や経営主体な どから分類すると以下のようになる（西村 2005)

(1)国公立自営型=国公立少年自然の家 - 青年 の家など、(2)民間独立型＝ホールアース自然学 校、国際自然大学校など、(3)民間部門型=キー プ協会 (環境教育事業部・キープ自然学校)、日 本旅行（トムソーヤクラブ）など、(4)民間ボラ ンティア型二京都自然教室など、(5)民間企業 $\mathrm{CSR}$ 型=トヨタ白川郷自然学校、市村自然塾 （リコー）など、(6)大学・学校型=金沢大学角間 の森自然学校、青森自然学校など、(7)行政・ $\mathrm{NPO}$ パートナーショップ型＝田貫湖ふれあい 自然塾、大杉谷自然学校など、(8)ネットワーク 型=いしかわ自然学校など

\section{生活系環境教育}

そもそも環境教育を「自然系」「生活系」と区 別すること自体あまり重要とは思えないが、自 然の中で行う環境教育の場の象徵的な存在を 「自然学校」と呼ぶが故に、自然を学びの場とは しない環境教育を「生活系」あるいは「都市系」 の環境教育という言い方をすることがある。し かし、自然学校の中には、自然体験そのものよ りも「生活」そのものにフォーカスをあてて、 「生き方、暮らし方」を体験を通して学ぶことを 活動の中心としているところも多い。自然学校
と呼ばれるからそれが直ちに自然体験中心とい うことでは決してなく、参加者が日常の生活に 戻ってからの生活にも反映されるような生活系 のプログラムを行っている所も少なくない。ま た、宿泊型のプログラムのための施設を持って いる自然学校などでは、自然学校での生活その ものが環境教育にもつながると考えている団体 も多い。

都市部では、リサイクル活動などを進める市 民団体の中で、その普及活動という意味での環 境教育を実践している団体がある。小学校など への出前授業なども行われ、教員からも教科教 育ではカバーしきれない部分の教育支援として 歓迎されている。

\section{企業と環境教育}

企業における環境教育が本格的に行われるよ うになってきたのはまだ日が浅いと言っても良 いだろう。1996年に始まった環境マネジメント システムISO (国際標準化機構) 14001の中で、 従業員に対する自覚教育が求められ、その自覚 教育は実質的な環境教育となっていた。日本は 世界的に見てもISO14001取得が最も多い国で あり、ISOの普及とともに企業の環境教育（特 に社員に対する環境教育) が一気に広がったと 言っても良いであろう。また 2000 年以降はCSR (企業の社会的責任)の視点から、企業活動の社 会への責任ある対応がより強く求められるよう になり、企業における環境教育の取り組みを加 速させているようだ。さらにCSRの考え方も従 来のコンプライアンス (法令順守)、ガバナンス 
(企業統治)、リスクマネジメント（危機管理） から、「生態系や生物多様性の保護」を本質と考 えるような考え方も出始め、そうした観点から 自然を舞台にした環境教育の必要性も指摘され るようになってきた。

企業における環境教育の取り組みは、各社が 発行している環境報告書 (サステナビリティ・ レポートなど様々な呼称がある)に見ることが 出来る。IIHOE (人と組織と地球のための国際 研究所) の調べ (2004年度) によれば、環境報告 書を発行している約 100 社の中で「環境教育」 の記述がなかったのはわずか数社だけであり、 報告書を出している企業の90数\%が何らかの形 での環境教育を実践していたという結果があ る。報告書に書かれている企業の環境教育とし ては以下のようなものがあった。

(1)ISO 環境マネジメントシステム関連の研 修、(2)全従業員を対象にした e ラーニング、 各階層別研修時の環境教育、(4)各専門領域別研 修時の環境教育、(5)社内報やホームページなど での情報発信・情報共有、(6)社内での各種顕彰 制度 (各種コンテスト)、(7)著名人による講演会 や映画会、8従業員の家族も対象にした環境家 計簿、9NGO P地元行政との協働事業、(11)社 内ボランティアの育成や支援、(11)森づくりや植 林活動の実施、12社員による環境経営への提案 制度、(13)具体的な自然に対する保護活動（資金 的支援)、(14)杖ンティアとしての支援

\section{おわりに}

これからの環境教育の大きなキーワードは
$\lceil\mathrm{ESD}$ (持続可能な開発のための教育)」と「コラ ボレーション(協㗢・連携)」だろう。ESDはこ の特集で阿部治氏が詳しく述べているので重複 は避けよう。複数のセクターが力を合わせて環 境教育を実施することが非常に重要なポイント になる。NPO同士のコラボレーションはもと より、NPO、企業、行政、さらに研究教育機 関などによる様々な組み合わせの可能性に期待 がかかる。私たち人類が直面している環境の問 題を解決するために、それぞれの環境教育セク ターはその知恵や経験やノウハウを積み重ねて きた。環境問題解決のための一つの方法である 環境教育の質的な向上のためには、そうした知 恵や経験やノウハウのさらなる交流が欠かせな い。また協働は打互いの働きのチェック機能を 果たすだけではなく、お互いの働きを社会に向 けてもオープンにし、その結果として社会的な 信用力も増大させることにもつながってゆくと いうことも忘れないでおきたいことだ。近年施 行された環境教育推進法 (通称) の中でも、こ の協働は大切なキーワードとしてその重要性が 強調されているのだが、協働はまだまだこれか らの課題ということであろう。ますますの協働 が期待される。

\section{参考文献}

日本環境教育フォーラム『日本型環境教育の提案』(小学館) 1992年改訂版2000年

岡島成行『自然学校をつくろう あなたも自然体験活動のリ ーダーになれる』(山と渓谷社) 2001年

西村仁志『自然学校の発展と課題』(同志社大学大学院総合 政策科学研究科) 2006 年

岡本享二『CSR入門』(日経文庫) 2004年 